Research Article

\title{
Immunomodulatory Activity of Methanol Leaf Extract of Neem (Azadirachta indica Juss) Against Suppressor and Proinflammatory Molecules
}

\author{
Supriyanto ${ }^{1,2 *}$, Simon Bambang Widjanarko ${ }^{3}$, Muhaimin Rifa'i ${ }^{4}$, Yunianta ${ }^{3}$ \\ ${ }^{1}$ Postgraduate of Agroindustrial Technology Program, Faculty of Agricultural Technology, Brawijaya University, \\ Malang 65145, Indonesia \\ ${ }^{2}$ Department of Agroindustrial Technology, Faculty of Agriculture, University of Trunojoyo Madura, Bangkalan \\ 69162, Indonesia \\ ${ }^{3}$ Department of Food Science and Technology, Faculty of Agricultural Technology, Brawijaya University, Malang \\ 65145, Indonesia \\ ${ }^{4}$ Department of Biology, Faculty of Mathematics and Natural Sciences, Brawijaya University, Malang 65145, \\ Indonesia
}

Article history:

Submission May 2021

Revised May 2021

Accepted August 2021

*Corresponding author:

E-mail: priyantosby17@gmail.com

\begin{abstract}
Neem plant is rich in bioactive constituents, which make it massively discussed the treatment of various diseases. A study on the immunomodulatory activities of neem is given here. This current work aimed to investigate the effects of neem leaf extract on immunocompetent cells. In vivo experiment was carried out using mice (Mus musculus) induced with DMBA, comprising positive control, negative control, and treatments of neem leaf extracts (250, 500, and $1000 \mathrm{ppm})$. Data obtained from flow cytometric analysis were evaluated using BD Cellquest ProTM software, then statistically analyzed in SPSS version 21. Parametric analysis in oneway ANOVA was performed at a significance level of 5\%. The significant difference was compared in the Duncan test. The results showed that administration of neem leaf extracts significantly affected the expression of $\mathrm{CD} 4^{+}, \mathrm{CD}^{+}, \mathrm{CD} 25^{+}$, CD62L, IL-10, and IL-17 cells. Neem leaf extract has immunomodulatory activities by increasing pressure molecules and decreasing pro-inflammatory molecules.
\end{abstract}

Keywords: Cytokine, Immunocompetent cells, Immunomodulator, Neem

\section{Introduction}

Cancer is a disease that is very dangerous and deadly in the world. According to WHO data, cancer is the second leading cause of death in the world. In 2018 there were 18.1 million cases of cancer and 9.6 million deaths [1]. The incidence rate of cancer in Indonesia (136.2 / 100,000 population) ranks 8th in Southeast Asia, while in Asia, it is 23rd. For men, the highest incidence rate in Indonesia is lung cancer, 19.4 per 100,000, with average mortality reaching 10.9 per 100,000 . Furthermore, liver cancer is in second place with a case rate of 12.4 per 100,000 , while the average death rate reached 7.6 per 100,000 . While the highest incidence rate for women is breast cancer, which is 42.1 per 100,000 population with an ave- rage death rate of 17 per 100,000 population, followed by cervical cancer at 23.4 per 100,000 population with an average death rate of 13.9 per 100,000 population [2]. One of the cancer treatments so far is chemical therapy or chemotherapy. However, this method of treatment has disadvantages besides being large in cost and having side effects. Many kinds of research have been carried out for cancer treatment using various herbal medicines in recent decades. The ability of herbal medicines as anticancer is due to the presence of bioactive that function as antioxidants, anti-bacterial, anti-inflammatory, and immune modulatory. Immunomodulators are substances or drugs that can reverse the imbalance of the immu-

\section{How to cite:}

Supriyanto, Widjanarko SB, Rifa’i M, Yunianta (2021) Immunomodulatory Activity of Methanol Leaf Extract of Neem (Azadirachta Indica Juss) Against Suppressor and Proinflammatory Molecules. Journal of Tropical Life Science 11 (3): 309 316. doi: 10.11594/jtls.11.03.07. 
ne system that is disturbed by stimulating and improving the function of the immune system.

Bioactive compounds in plants and fruits, named as phytochemicals in pharmacy, have been massively reported to exert protective activities against acute and chronic diseases in humans. The content of phenolic compounds in seaweed may reduce the risk of colon cancer [3]. Hexagonia glabra mushroom has potential as an anticancer agent and [4].

Another plant that has a positive effect on health is neem (Azadirachta indica Juss.). Neem is a tree whose trunk can reach $20 \mathrm{~m}$. It has thick skin, slightly rough stems, even pinnate leaves, and an oval shape with jagged and pointed edges, while the fruit is a stone fruit with a length of 1 $\mathrm{cm}$. Neem fruit is produced one to two times a year, is oval, when ripe the flesh is yellow, the seeds are covered with hard brown skin and inside are attached a white rind. The trunk is slightly bent and short; therefore, the wood is not large. The neem plant has several uses. In India, this plant is called the village pharmacy, where neem is used to cure skin diseases, anti-inflammatory, fever, antibacterial, antidiabetic, cardiovascular disease, and insecticides [5]. Health-promoting properties of the neem plant are widely discussed, in which these activities are attributed to the presence of bioactive compounds such as polyphenol and flavonoid [6]. Neem leaves contain several health-promoting compounds such as $\beta$-sitosterol, hyperoside, nimbolide, quercetin, quercitrin, rutin, azadirachtin, and nimbine. These compounds showed anticancer activity [7]. Numerous studies of neem bioactivities covered many topics, including antibacterial $[3,8]$, antioxidant $[9,10]$, anticancer [11], and immunomodulatory activities $[12,13]$.

Immunomodulation of the neem leaf extract occurred by altering the peritoneal macrophages population in experimental animals [13]. Research found that extract of neem leaves enabled to stimulation of expression of IFN $\gamma$ and components of immune surveillance cells (NK cell, T cytotoxic cell $\left(\mathrm{CD}^{+}\right)$, and macrophage) as observed in benzo(a)pyrene-induced mice [12].

To date, studies on immunomodulatory activity of methanolic extract from neem leaf focusing mainly on $\mathrm{CD}^{+}, \mathrm{CD}^{+}, \mathrm{CD} 25^{+}$, and $\mathrm{CD} 62 \mathrm{~L}$ observed using flow cytometric analysis are scarcely reported. Therefore, this present work investigates the effect of methanolic extract of neem leaf as an immunomodulator on $\mathrm{CD}^{+}, \mathrm{CD}^{+}, \mathrm{CD} 25^{+}$, and

\section{CD62L cells.}

\section{Material and Methods Experimental procedures}

Twenty-five experimental animals (DDY mice, an average body weight of $200 \mathrm{~g}$ ) were obtained from LPPT, Yogyakarta. Before the main experiment, acclimatization of the animals was carried out for seven days, in which they were fed and weighed daily during this period. The mice were then divided into five groups (comprising five animals in each group), i.e., group 1: negative control (normal), group 2: positive control (cancer), group 3: cancer-induced mice treated with neem leaf extract of $250 \mathrm{ppm}$, group 4: cancer-induced mice treated with neem leaf extract of 500 ppm, and group 5: cancer-induced mice treated with neem leaf extract of $1000 \mathrm{ppm}$.

Intraperitoneal injection of DMBA was carried out weekly for six weeks to the healthy mice (previously acclimatized for seven days) of groups $2,3,4$, and 5 , enabling to induce growth of cancer cells. The dose of DMBA injection is weight-independent. After confirming the cancer status by the presence of necrotic cells, the neem leaf extract was orally administered to mice at different levels $(0-1000 \mathrm{ppm})$ for 14 days.

After completion of treatments, the animals were sacrificed, dissected from left dorsal to ventral. The spleen was collected and crushed with PBS (phosphate buffer solution) and then transferred into $15 \mathrm{ml}$-propylene tubes. The tubes were centrifuged at $2500 \mathrm{rpm}\left(10^{\circ} \mathrm{C}, 5 \mathrm{~min}\right)$, then the supernatant was removed. The resuspension of the pellet was carried out using $1 \mathrm{~mL}$ of PBSA

\section{Flow Cytometric analysis}

After incubation, cells were harvested and centrifuged at $2500 \mathrm{rpm}\left(10^{\circ} \mathrm{C}, 5 \mathrm{~min}\right)$. Pellet was resuspended in $1 \mathrm{~mL}$ of PBS, transferred into four microtubes, and centrifuged, allowing for removal of the supernatant. The pellet was then stained using a combination of conjugated antibodies, i.e. (1) Fluorescein isothiocyanate (FITC)-conjugated rat anti-mouse CD4, Phycoerythrin (PE)-conjugated rat anti-mouse CD25 and $\mathrm{PE} / \mathrm{Cy} 5$ conjugated rat anti-mouse CD62L; (2) FITC-conjugated rat anti-mouse $\mathrm{CD} 4, \mathrm{PE}$-conjugated rat anti-mouse CD8; (3) FITC-conjugated rat anti-mouse CD4, $\mathrm{PE}$-conjugated rat anti-mouse IFN $\gamma$ and $\mathrm{PE} / \mathrm{Cy} 5-$ conjugated rat anti-mouse TNF- $\alpha$ and (4) FITCconjugated rat anti-mouse CD11B, PE-conjugated 



Figure 1. The relative number of CD4+ cells in mice treated with different levels of neem leaves extracts. Note: (A) negative control/normal, (B) Dose/Cancer, (C) 250 ppm, (D) 500 ppm, and (E) 1000 ppm.

rat anti-mouse IFN $\gamma, \mathrm{PE} / \mathrm{Cy5}$-conjugated rat antimouse NF-kB and APC-conjugated rat anti-mouse IL-6. The cells stained with the extracellular antibody were incubated for $20 \mathrm{~min}$ in an icebox. A fixative solution $(50 \mu \mathrm{L})$ of cytosis/cytoplasm was added and incubated for $20 \mathrm{~min}$ in the icebox. Alternatively, a rinse solution $(500 \mu \mathrm{L})$ was added and centrifuged. The supernatant was discarded, while the pellet was stained using an intracellular antibody and incubated for 20 min in an icebox. PBS $(500 \mu \mathrm{L})$ was added to both cell groups. Each sample was transferred into cuvet for flow cytometric analysis in the flow cytometer

\section{Data analysis}

Data obtained from flow cytometric analysis were evaluated using BD Cellquest ProTM software, then statistically analyzed in SPSS version 21. Parametric analysis followed one-way ANOVA at a significance level of $5 \%$. The significant difference was compared in the Duncan test.

\section{Results and Discussions}

The $\mathrm{T}$ helper cells, also recognized as $\mathrm{CD} 4^{+}$ cells, play a pivotal role in the immune system. Our experimental results showed that the treatments arranged demonstrated a significant difference in the number of $\mathrm{CD}^{+}$cells. The cells in the cancer group tended to alleviate in comparison with those in the normal group. Meanwhile, mice treated with neem leaf extracts possessed a notice- able increase in $\mathrm{CD}^{+}$cells over cancer-induced mice. The reduced number of $\mathrm{CD} 4^{+}$cells in cancer groups was mainly linked to protective activity against foreign disease and virus attacks. We found that the number of $\mathrm{CD} 4^{+}$cells increased in mice treated with neem leaf extract, as exhibited in Figure 1.

This increment may relate to the role of bioactive compounds in neem leaf extract responsible for immunostimulatory, particularly activation of $\mathrm{CD} 4^{+}$cells. Saponin and flavonoid are of foremost bioactive compounds in neem leaf extract, allowing to induce secretion of cytokinin associated with the activity of $\mathrm{CD}^{+}$cells such as IFN $\gamma$ and IL2. The study showed that saponin could upregulate $\mathrm{T}$ helper cells by stimulating the number of IFN $\gamma$ [14]. The IFN $\gamma$ demonstrated a key role in the upregulation of MHC-II, thereby increasing the proliferation of $\mathrm{CD}^{+}$cells. Besides, flavonoids served as immunostimulants by increasing the production of IL-2 [15]. IL2 could be induced by mitogens [16]. The research found that mitogen-activated protein kinases (MAPKs) regulate cell proliferation, allowing to catalyze the phosphorylation of cellular substrate that facilitates the proliferation of B cells and T cells [17].

\section{$\mathrm{CDB}^{+}$cells in treated mice}

The results showed that the administration of neem leaf extracts significantly altered the number of $\mathrm{CD}^{+}$cells $(\mathrm{p}<0.05)$. Based on Figure 2 , the 

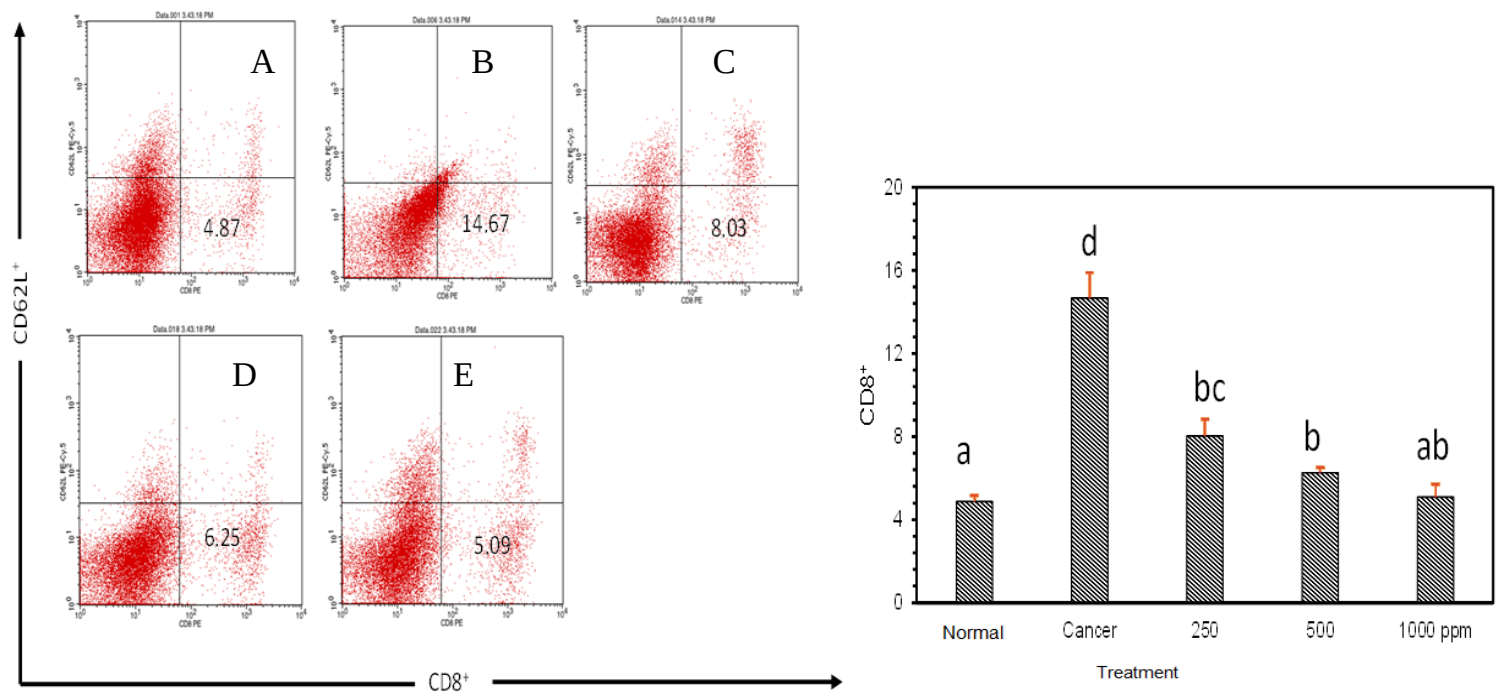

Figure 2. The relative number of CD8+ cells in mice treated with different levels of neem leaf leaves extracts. Note: (A) negative control/normal, (B) Dose/Cancer, (C) 250 ppm, (D) 500 ppm, and (E) 1000 ppm.

relative number of $\mathrm{CD}^{+}$cells was higher in cancer groups than in the normal group. Interestingly, a decrease of $\mathrm{CD}^{+}$cells occurred in mice treated with neem leaf extract compared to cancer induced mice.

The number of $\mathrm{CD}^{+}$cells tended to increase in cancer groups due to their role as suppressor $\mathrm{T}$ cells capable of reducing the development of cancer cells. In mice treated with neem leaf extract, the larger quantity of $\mathrm{CD}^{+}$cells was ascribed to the role of saponin and flavonoid as active constituents, enabling modulation of the production of IL-2 in $\mathrm{CD}^{+}$cells. The increase in IL-2 would alter the increment of $\mathrm{CD}^{+}$cells. [18] found that IL-2 induced activation of $\mathrm{CD}^{+}$, contributing to the synthesis of perforin and granzyme. Both constituents can degrade infected cells. The $\mathrm{CD}^{+}$ cells doubled several times as a response to the infections [19].

\section{The effect of neem leaf extract on $C D 62 \mathrm{~L}$}

The naive $\mathrm{T}$ cells $\left(\mathrm{CD} 4{ }^{+} \mathrm{CD} 62 \mathrm{~L}^{+}\right)$constitute mature lymphocyte cells that migrate from the thymus, are not differentiated, and are exposed to their specific antigen. The activation of $\mathrm{T}$ cells leads them to the process of differentiation into effector $\mathrm{T}$ cells and memory cells, followed by their migration into lymphoid and non-lymphoid tissues [20]. In this work, the administration of neem leaf extract promoted a significant difference in the amount of $\mathrm{CD} 4^{+} \mathrm{CD} 62 \mathrm{~L}^{+}$. As shown in Figure 3 , there was a decrease in the relative number of $\mathrm{CD} 4{ }^{+} \mathrm{CD}_{2} \mathrm{~L}^{+}$in cancer mice and neem treatment.
The reduced amount of $\mathrm{CD} 4{ }^{+} \mathrm{CD} 62 \mathrm{~L}^{+}$was associated with activation of $\mathrm{CD} 4{ }^{+} \mathrm{CD} 62 \mathrm{~L}^{+}$previously existed as naive cells, induced by the presence of cancer cells. [18] asserted that CD62L constituted a marker for cell activation; thus, the reduced number of CD62L T cells could indicate activation of naive $\mathrm{T}$ cells into $\mathrm{CD} 4^{+}$. The decreasing expression of $\mathrm{CD} 62 \mathrm{~L}$ in immature $\mathrm{T}$ cells $\left(\mathrm{CD} 4^{+}\right.$ $\mathrm{CD} \mathrm{L}^{+}$) suggests that $\mathrm{T}$ cells require CD62L to attach and roll on the endothelial cells in blood vessels. The CD62L expression was very high in naive $T$ cells but lower in activated $T$ cells. It modulated the migration of naive $\mathrm{T}$ cells into lymph nodes in which antigen and immune response initiation existed [21]. The expression of CD62L resulted from TCD4 ${ }^{+}$proliferation and occurred as a response to stimulation from antigen [22].

The number of $\mathrm{CD}^{+} \mathrm{CD}^{+} 2 \mathrm{~L}^{+}$cells increased due to stimulation induced by flavonoids present in the neem leaf extract. The increasing amount of naive $\mathrm{T}$ cells and memory cells in the infectious group is closely related to the mitogen of neem leaf extract. The mitogen originating from plants enhanced the immune system's proliferation and differentiation of $\mathrm{T}$ and $\mathrm{B}$ cells. The alteration of the relative number of $\mathrm{CD} 4{ }^{+} \mathrm{CD} 62 \mathrm{~L}^{+}$in treated mice than in the normal group caused by neem leaf extract was exhibited in Figure 3.

\section{The effect of neem leaf extract on $C D 25^{+}$}

Based on statistical analysis, neem leaf extract had a significant effect on $\mathrm{CD}_{2} 5^{+}$at the $\alpha 5 \%$ significance level. Our experiment showed an increa 



Figure 3. The relative number of CD4+CD62L+ cells in mice treated with different levels of neem leaves extracts. Note: (A) negative control/normal, (B) Dose/Cancer, (C) 250 ppm, (D) 500 ppm, and (E) 1000 ppm.
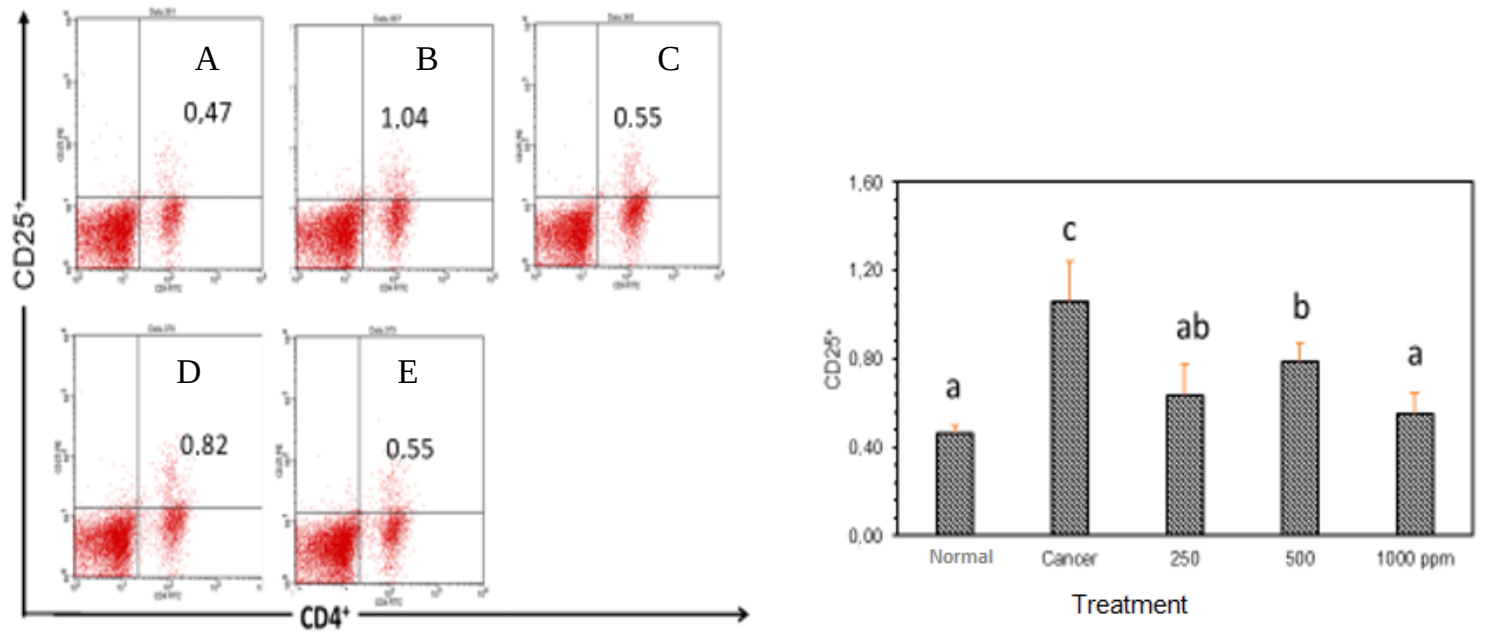

Figure 4. The relative number of CD25+ cells in mice treated with different levels of neem leaf extracts. Note: (A) negative control/normal, (B) Dose/Cancer, (C) 250 ppm, (D) 500 ppm, and (E) 1000 ppm.

se of $\mathrm{CD} 25^{+}$in cancer mice, but a profound decrease in $\mathrm{CD}^{2} 5^{+}$was observed in mice treated with neem leaf extract of 500 ppm compared with normal mice, as depicted in Figure 4.

$\mathrm{CD}^{2} 5^{+}$is a transmembrane glycoprotein and component for the receptor of IL-2. Our experiment showed an increase of $\mathrm{CD}_{2} 5^{+}$in cancer mice, but a profound decrease in $\mathrm{CD} 25^{+}$was observed in mice treated with neem leaf extract of $500 \mathrm{ppm}$ compared with normal mice, as depicted in Figure 4. The significant increase of $\mathrm{CD} 25^{+}$was associated with saponin and flavonoids present in the neem leaf extract. The saponin and flavonoid could stimulate the response of cellular immune through rising production of IL-2 and IFNy. The rise of IL-2 da Figure 4 . The relative number of CD25 ${ }^{+}$cells in mice treated with different levels of neem leaf extracts $\mathrm{n}$ IFN $\gamma$ indirectly promoted $\mathrm{CD}^{+} \mathrm{T}$ cell precursor differentiation to $\mathrm{CD} 4^{+} \mathrm{CD} 25^{+} \mathrm{T}$ cells.

\section{The effect of neem leaf extract on IL-10 Cell ex- pression in mice}

Statistically, the significant impact of neem leaf extract on the number of IL-10 was observed in normal and treated mice. Figure 5 shows the 

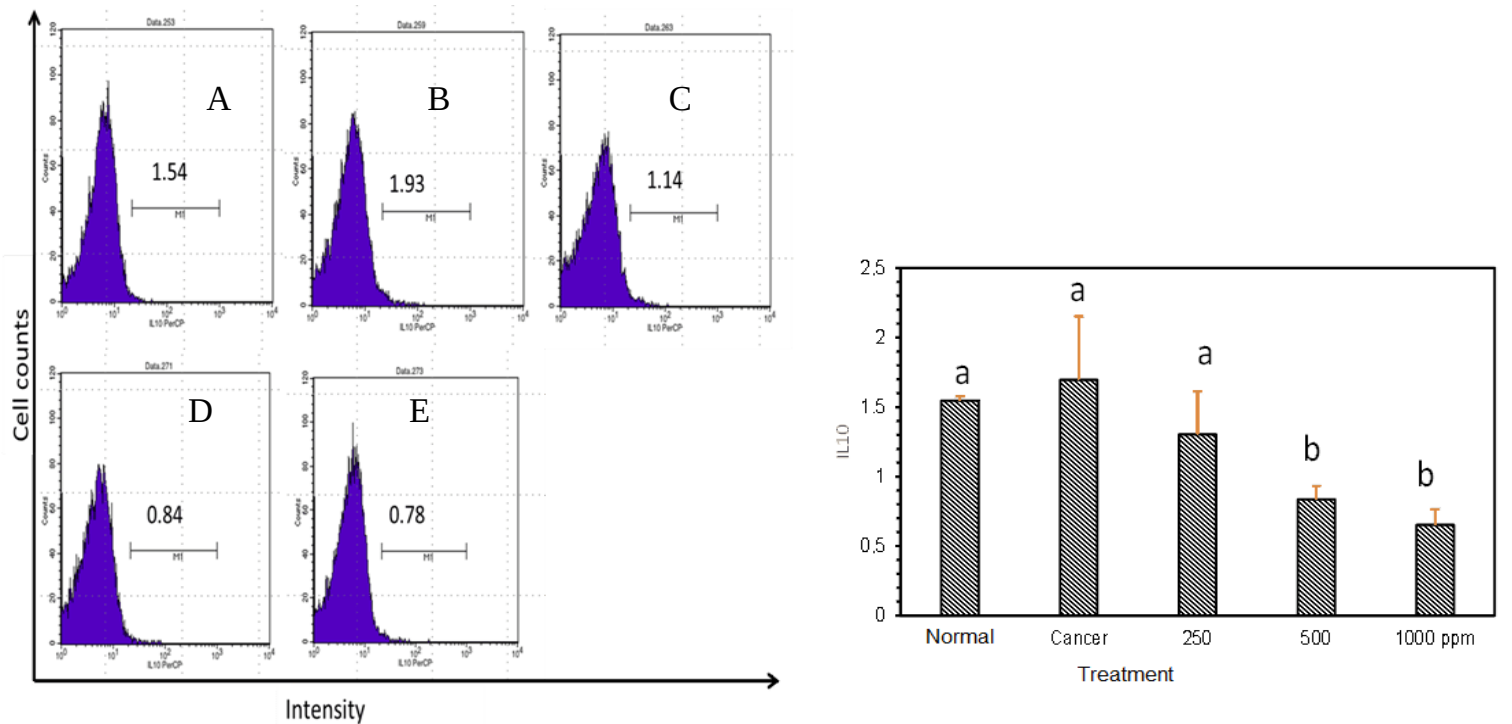

Figure 5. The relative number of IL-10 cells in mice treated with different levels of neem leaves extracts. Note: (A) negative control/normal, (B) Dose/Cancer, (C) 250 ppm, (D) 500 ppm, and (E) 1000 ppm.
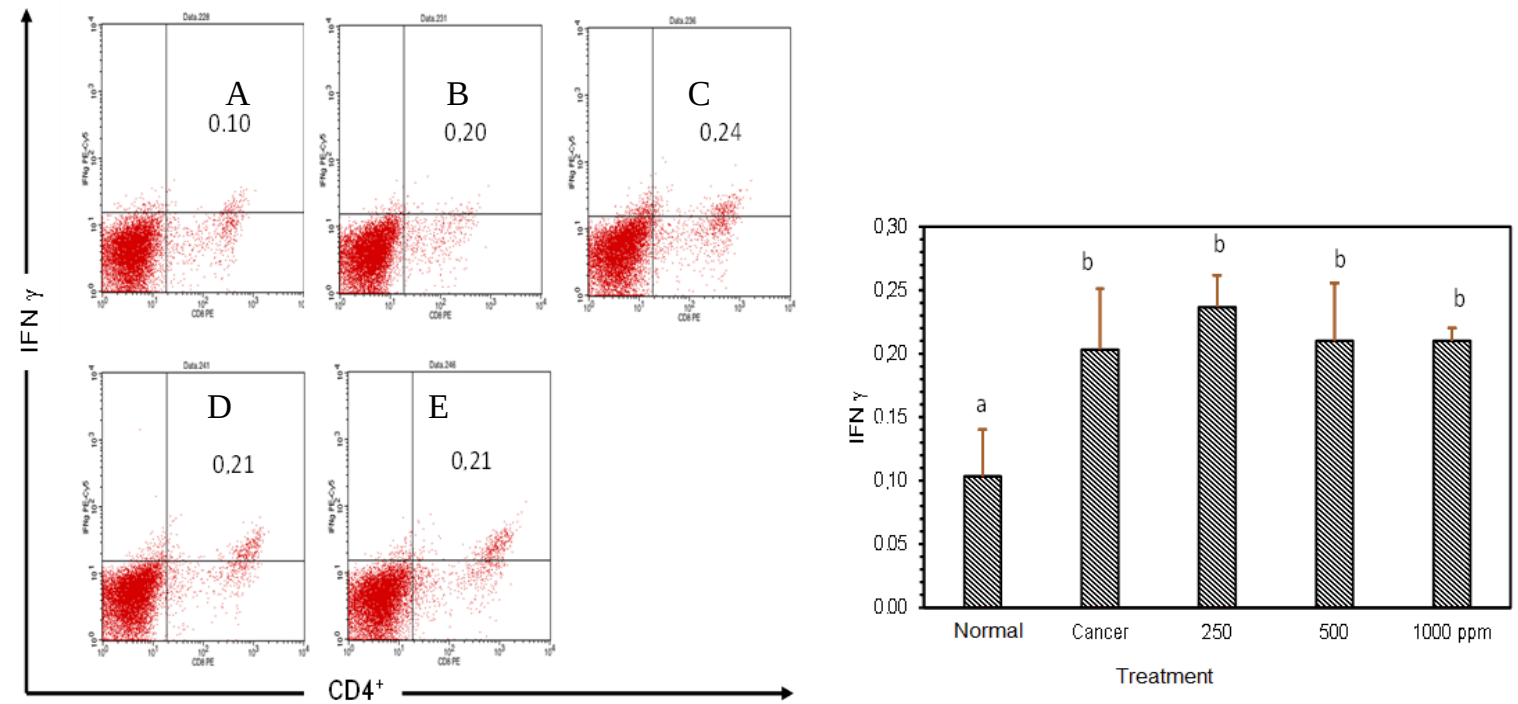

Figure 6. The relative number of IL-17 cells in mice treated with different levels of neem leaf extracts. Note: (A) negative control/normal, (B) Dose/Cancer, (C) 250 ppm, (D) 500 ppm, and (E) 1000 ppm.

effect of neem leaf extract on IL10. The more neem leaf extract that is used causes the amount of IL-10 to decrease.

Interleukin 10 (IL-10) exhibited the most potent anti-inflammatory cytokine, serving as a central response against pathogens, protecting hosts, as well as regulating homeostasis in normal tissues [23]. The polyphenol exerted several promising bioactivities such as antioxidants, anti-inflammation, and anticancer. The mode action of anticancer properties by polyphenol is based on blocking IL-10 secretion and sensor for IL-12 secretion [24]. IL-12 modulates the secretion of IFN $\gamma$ [25].
The effect of neem leaf extract on the expression of IL-10 was presented in Figure 5.

\section{The effect of neem leaf extract on IL-17 Cel ex- pression in mice}

Interleukin-17 (IL-17) is a pro-inflammatory cytokine and is generated by Th17 [26]. The results showed that the relative number of IL-17 cells significantly differed between normal and cancer and treated mice.

As depicted in Figure 6, the number of IL-17 cells in cancer mice was higher than that in normal mice, while treated mice showed the lowest num- 
ber of IL-17. The higher number of IL-17 cells in cancer mice resulted from inflammation. However, treatment of neem leaf extracts could suppress the expression of IL-17, enabling to inhibit of inflammation and reduce transcription of Th1 and Th17.

\section{Conclusion}

The study demonstrated that neem leaf (Azadirachta indica Juss) extract has immunomo-dulatory activities, especially at the concentration of $500 \mathrm{ppm}$. Neem leaf extract affects increasing cell $\mathrm{T} \mathrm{CD4}^{+}$and $\mathrm{CD}^{+}$, pressure anti-inflammatory cytokine IL10, and decreasing pro-inflammatory cytokine IL17.

\section{Acknowledgement}

The authors would like to acknowledge Directorate General of Higher Education for providing a research grant.

\section{References}

1. WHO (2021) Cancer. https://www.who.int/healthtopics/cancer\#tab=tab_1. Accessed: 5 May 2021

2. Kemenkes RI (2019) Hari Kanker Sedunia 2019. https://www.kemkes.go.id/article/view/19020100003/ha ri-kanker-sedunia-2019.html. Accessed: 3 May 2021

3. Orhue PO, Momoh AR, Igumbor EO, Esumeh FI (2014) Antibacterial effect of Azadirachta indica ( CN : Neem or Dongo Yaro) parts on some urinary tract bacterial isolates. Asian Journal of Plant Science and Research 4 (2): 64-67.

4. Ghosh SK, Sanyal T, Bera T (2020) Anticancer Activity of Solvent Extracts of Hexogonia glabra against Cervical Cancer Cell Lines. 21 1977-1986. doi: 10.31557/APJCP.2020.21.7.

5. Puri H. (2006) Neem The Divine Tree.

6. Ghimeray AK, Jin C, Ghimire BK, Cho DH (2009) Antioxidant activity and quantitative estimation of azadirachtin and nimbin in Azadirachta indica A . Juss grown in foothills of Nepal. Afrika Jurnal Bioteknologi 8 (13): 3084-3091.

7. Pankaj S, Lokeshwar T, Mukesh B, Vishnu B (2011) Review On Neem ( Azadirachta indica): Thousand Problems One Solution. International Research Journal Of Pharmacy 2 (12): 97-102.

8. Chaube SK, Shrivastav TG, Tiwari M et al. (2014) Neem (Azadirachta indica L.) leaf extract deteriorates oocyte quality by inducing ROS-mediated apoptosis in mammals. Springerplus. doi: 10.1186/2193-1801-3-464

9. Shrivastava DK, Swarnkar K (2014) Original Research Article Antifungal Activity of leaf extract of Neem (Azadirachta indica Linn ). 3 (5): 305-308.

10. Balaji G, Cheralathan M (2015) Experimental investigation of antioxidant effect on oxidation stability and emissions in a methyl ester of neem oil fueled DI diesel engine. Renewable Energy 74 (x): 910-916. doi: 10.1016/j.renene.2014.09.019.

11. Othman F, Motalleb G, Peng SLT, Grace A FS and PC (2011) Extract of Azadirachta indica (Neem) Leaf Induces Apoptosis in 4T Breast Cancer BALB/c Mice. 13 (2): 107-116.

12. Dayakar A, Chandrasekaran S, Veronica J et al. (2015) In vitro and in vivo evaluation of anti-leishmanial and immunomodulatory activity of Neem leaf extract in Leishmania donovani infection. Experimental Parasitology 153 (March): 45-54. doi: 10.1016/j.exppara.2015.02.011.

13. Abror YK, Woelansari ED, Suhariyadi S (2018) Immunomodulator of Ethanol Extracts of The Leaves Azadirachta indica Against Macrophage Peritoneal Cell in Mice Induced The Vaccine BCG. Jurnal Teknologi Laboratorium 8 (1): $\quad 8-14 . \quad$ doi: 10.29238/teknolabjournal.v7i1.110.

14. Cheeke P (2000) Actual and potential applications of Yucca schidigera and Quillaja saponaria saponins. Journal of Animal Science: 241-254.

15. Lyu SY, Park WB (2005) Production of cytokine and NO by RAW 264.7 macrophages and PBMC in vitro incubation with flavonoids. Archives of Pharmacal Research 28 (5): 573-581. doi: 10.1007/BF02977761.

16. Goodman JW (2004) The immune response. In: Stites DP, Terr AI PT ed Basic Clin. Immunol., 8th ed. New Jersey, Prentice-Hall International In. pp 40-41.

17. Nworu CS, Akah PA, Okoye FBC et al. (2010) The effects of Phyllanthus niruri aqueous extract on the activation of murine lymphocytes and bone marrowderived macrophages. Immunological Investigations 39 (3): 245-267. doi: 10.3109/08820131003599585.

18. Mcnally A, Hill GR, Sparwasser T et al. (2011) effector differentiation by modulating IL-2 homeostasis. 108 (18): 7529-7534. doi: 10.1073/pnas.1103782108.

19. Abbas, Abul K, Lichtman, Andrew H; Pillai S (2011) Cellular and molecular immunology. 6th ed. Philadelphia: Saunders.

20. Karnen Garna Baratawidjaja dan Iris Rengganis (2010) Imunologi dasar. Ed. 8. Jakarta, Balai Penerbit Fakultas Kedokteran Universitas Indonesia.

21. Rifa'i M (2011) Imunologi dan Bioregulator. 1st ed. Malang, UB Press.

22. Karrer U, Sierro S, Wagner M et al. (2003) Memory Inflation: Continuous Accumulation of Antiviral CD8 + T Cells Over Time . The Journal of Immunology 170 (4): 2022-2029. doi: 10.4049/jimmunol.170.4.2022.

23. Iyer SS, Cheng G (2012) Role of interleukin 10 transcriptional regulation in inflammation and autoimmune disease. Critical Reviews in Immunology 32 (1): 23-63. doi: 10.1615/critrevimmunol.v32.i1.30.

24. Tosetti F, Ferrari N, De Flora S, Albini A (2002) 'Angioprevention': angiogenesis is a common and key target for cancer chemopreventive agents. The FASEB Journal 16 (1): 2-14. doi: 10.1096/fj.01-0300rev.

25. Abbas AR, Baldwin D, Ma Y et al. (2005) Immune response in silico (IRIS): Immune-specific genes identified from a compendium of microarray expression data. Genes and Immunity 6 (4): 319-331. doi: 10.1038/sj.gene.6364173. 
26. Fabre L, Le Hello S, Roux C et al. (2014) CRISPR Is an Optimal Target for the Design of Specific PCR Assays for Salmonella enterica Serotypes Typhi and Paratyphi A.
PLoS Neglected Tropical Diseases 8 (1): 14. doi: 10.1371/journal.pntd.0002671. 